\title{
Seasonal and latitudinal variations in the energy reserves of the mud fiddler crab Uca pugnax: implications for the response to climate change
}

\author{
Renae J. Brodie ${ }^{1, *}$, Beryl Roberts ${ }^{1}$, Jessica I. Espinosa ${ }^{2}$, Katrina Heilman ${ }^{1}$, \\ Stephen A. Borgianini ${ }^{3}$, James M. Welch ${ }^{4}$, Kathleen A. Reinsel ${ }^{4}$
}

\author{
${ }^{1}$ Department of Biological Sciences, Mount Holyoke College, South Hadley, Massachusetts 01075, USA \\ ${ }^{2}$ Department of Ecology, Evolution and Environmental Biology, Columbia University, New York, New York 10027, USA \\ ${ }^{3}$ Department of Natural Sciences, University of South Carolina, Beaufort, South Carolina 29902, USA \\ ${ }^{4}$ Department of Biology, Wittenberg University, PO Box 720, Springfield, Ohio 45501, USA
}

\begin{abstract}
In 2014, the Atlantic mud fiddler crab Uca pugnax was found $80 \mathrm{~km}$ north of its previously known northern range limit. Two years before this shift was noted, we collected a total of 781 male and female specimens from 6 populations along a latitudinal transect extending from Wareham, Massachusetts $\left(41.7615^{\circ} \mathrm{N}\right)$, to Tybee Island, Georgia $\left(32.0139^{\circ} \mathrm{N}\right)$, USA. By assessing latitudinal and seasonal patterns in the hepatosomatic index (HSI; a measure of stored energy) and the reproductive status of females, we sought to determine whether adult physiological and reproductive limits might slow the northern expansion of $U$. pugnax. We did not find a latitudinal cline for HSI, suggesting that $U$. pugnax is a thermal generalist; however, both males and females in the southern part of the range showed greater seasonal fluctuations in HSI compared to northern conspecifics. Across the range, ovigerous females had a significantly reduced HSI, revealing the cost of reproduction. Ovigerous females were found in the May 2013 collection in Massachusetts before ocean conditions were permissible for larval development and earlier than previously reported for this species. U. pugnax is expected to closely track warming conditions in the Northwest Atlantic because adults in northern populations are able to maintain energy stores comparable to that of their southern conspecifics, and they release planktonic larvae in early spring, maximizing their dispersal potential.
\end{abstract}

KEY WORDS: Range limit $\cdot$ Hepatosomatic index $\cdot$ Dispersal potential $\cdot$ Uca $\cdot$ Energetics

\section{INTRODUCTION}

The surface of the world's oceans has warmed at a rate of $0.1^{\circ} \mathrm{C}_{\text {decade }}^{-1}$ since 1971 (IPCC 2014), a pace of change that poses significant physiological challenges to marine life. As warming continues, species may persist in situ through directional selection if populations are sufficiently large and genetically diverse (Bell \& Gonzalez 2009, Hufbauer et al. 2015, Wootton \& Pfister 2015). However, evolutionary rescue will not be possible for the many species that lack the degree of genetic variation needed to keep apace

\footnotetext{
*Corresponding author: rbrodie@mtholyoke.edu
}

with environmental change (Bradshaw \& McNeilly 1991). Without evolutionary change within populations, species can persist if individuals are able to acclimate (Stillman 2002, Somero 2010, Seebacher et al. 2015), behaviorally thermoregulate (Sunday et al. 2014), or move to new locations where they are more physiologically adapted (Sunday et al. 2012). To predict how organisms might respond to climate change, we need to investigate how individuals interact with their environments through their behaviors, physiological experiences, and energetics (Buckley et al. 2014).

(C) The authors 2017. Open Access under Creative Commons by Attribution Licence. Use, distribution and reproduction are unrestricted. Authors and original publication must be credited. 
We examined latitudinal trends in energy reserves in the fiddler crab Uca pugnax to inform our understanding of how this species might respond to climate warming, especially in the northern part of its range. In 2012-2013 when the present study took place, $U$. pugnax was thought to have a species range extending from Massachusetts to northern Florida, USA (Miller \& Vernberg 1968, Barnwell \& Thurman 1984). Then, in 2014 it was recognized that $U$. pugnax had undergone a range shift when adult crabs were found for the first time in the salt marshes of New Hampshire, $80 \mathrm{~km}$ north of the previously known northern range limit (Johnson 2014). In 2016, small populations $\left(<1 \mathrm{crab} \mathrm{m}^{-2}\right.$ ) with ovigerous females were present in northern Massachusetts and New Hampshire, and a single individual had been collected in Maine (D. Johnson pers. comm.). Any range shift in this species has ecosystem-wide consequences: deposit feeding and burrowing by $U$. pugnax impact infaunal species densities (Hoffman et al. 1984), plant growth (Bertness 1985, Smith \& Tyrrell 2012, Gittman \& Keller 2013), decomposition rates (Thomas \& Blum 2010), and sediment accumulation or erosion, depending on site-specific characteristics (Katz 1980, Smith \& Green 2015). Also, burrow excavation is an activity that has been found to enhance carbon flux in other systems with burrowing semi-terrestrial crabs (Pülmanns et al. 2014). Finally, adult and larval U. pugnax are consumed by many other species, including larval and adult fishes, birds, and other crabs (Crane 1975).

It has been convincingly established that the northern range edge of this species is set by its inability to complete larval development in seawater colder than $18^{\circ} \mathrm{C}$ (Passano 1960, Sanford et al. 2006), so the northern expansion is likely due to recent warming in the Atlantic Ocean (Johnson 2014). While larval physiology clearly sets the northern limit in this species, the ability of populations to persist in the northern part of the range is also determined by adult crab physiological limits, including their abilities to acquire and maintain energy reserves.

$U$. pugnax, which forms dense populations in muddy areas of marshes, acquires energy at low tide by scraping exposed sediment with its chelipeds, consuming mostly diatoms (Weissburg 1993), but also bacteria, ciliates, and meiofauna (Teal 1958, Hoffman et al. 1984). In crustaceans, dietary lipids are stored in the hepatopancreas until they are mobilized for gamete production and the replacement of the integument during molting (Yamaguchi 2001, 2003). For this reason, we employed a common metric for assessing energy reserves, the hepatosomatic index (HSI) - the ratio of the mass of the hepatopan- creas to the total body mass commonly reported as a percentage. In other crustaceans, HSI has been used to assess how energetics are impacted by physiological and environmental factors, including seasonality and reproduction (e.g. Kyomo 1988, Zara et al. 2013, Liu et al. 2014), molting (e.g. Romano et al. 2014), diet (e.g. Bui \& Lee 2014, Wang et al. 2014, Silva-Castiglioni et al. 2016), and exposure to metals (e.g. Elumalai et al. 2005, Sabatini et al. 2009). Here, we explored how HSI varied by latitude and season for both male and female U. pugnax. Both northern and southern crabs are limited in their ability to feed by the timing of the tides and competing activities, such as courtship and mating, burrow maintenance and defense, predator avoidance, and travel to and from feeding areas. However, temperature impacts crabs differently along the species' range. During the northern hemisphere winter, the active season of northern crabs is shortened because they spend several months underground in a state of quiescence, which limits the time they can devote to acquiring energy for growth and reproduction (Wolcott 1988). In contrast, their southern conspecifics are able to feed during the coldest months on warm days (G. Townsend pers. comm.). Given this disparity in feeding time, we expected that northern crabs would have a lower HSI, overall, compared to their southern counterparts. To test this prediction, we compared energy reserves over the course of a year (20122013) in populations between Massachusetts and Georgia, USA.

\section{MATERIALS AND METHODS}

Crabs of both sexes were collected at 6 sites, spanning nearly $10^{\circ}$ latitude along the range of UCa pugnax (Fig. 1, Table 1): Buzzards Bay in Wareham, Massachusetts (MA) $\left(41.7615^{\circ}\right.$ N, 70.7197 W), Maurice River Marsh at the Haskin Shellfish Research Lab in Port Norris, New Jersey (NJ) $\left(39.2344^{\circ} \mathrm{N}\right.$, $\left.75.0369^{\circ} \mathrm{W}\right)$, Bell Creek Marsh in Beaufort, North Carolina (NC) $\left(34.7898^{\circ} \mathrm{N}, 76.6693^{\circ} \mathrm{W}\right)$, Marsh Road at the Belle Baruch Field Laboratory in Georgetown, South Carolina (SC) $\left(33.3298^{\circ} \mathrm{N}, 79.2082^{\circ} \mathrm{W}\right.$; hereafter, SC1), Buckingham Landing, Bluffton, SC $\left(32.2337^{\circ} \mathrm{N}, 80.8039^{\circ} \mathrm{W}\right.$; hereafter, SC2), and Tybee Island, Georgia (GA) $\left(32.0139^{\circ} \mathrm{N}, 80.8812^{\circ} \mathrm{W}\right)$. In $\mathrm{MA}, \mathrm{NC}$, and GA, specimens were collected on 4 occasions, beginning in July of 2012 and ending in August of 2013. Two SC sites were used-SC1 was used in the initial July 2012 collection, but a different site (SC2) was used for the subsequent 3 collections 
due to logistical complexities. The Port Norris, NJ, site was added after the initial July 2012 collection.

Crabs with carapace widths $\geq 10 \mathrm{~mm}$ were collected opportunistically, and approximately 20 individuals of each sex with no missing appendages or apparent injuries were taken in each collection period (see Table 1 for numbers of crabs collected). Crabs were kept alive in water from the site for several hours to clear their intestines for an accurate dry weight. The carapace width was measured at the widest point with digital calipers $(0.01 \mathrm{~mm})$. Crabs were then frozen and stored at $-80^{\circ} \mathrm{C}$ until they were thawed at room temperature and dissected. Specimens collected in NC, SC, and GA after July 2012 were shipped overnight on dry ice or frozen gel packs to Massachusetts. In some cases, not all of the shipped crabs were dissected or used in the analysis if they appeared too damaged (e.g. had missing appendages) or had sand in their intestines.

The hepatopancreas was dissected out using fine forceps under a dissecting microscope. The large male claw, body, and hepatopancreas were dried separately in a $60^{\circ} \mathrm{C}$ oven for at least $24 \mathrm{~h}$ and weighed

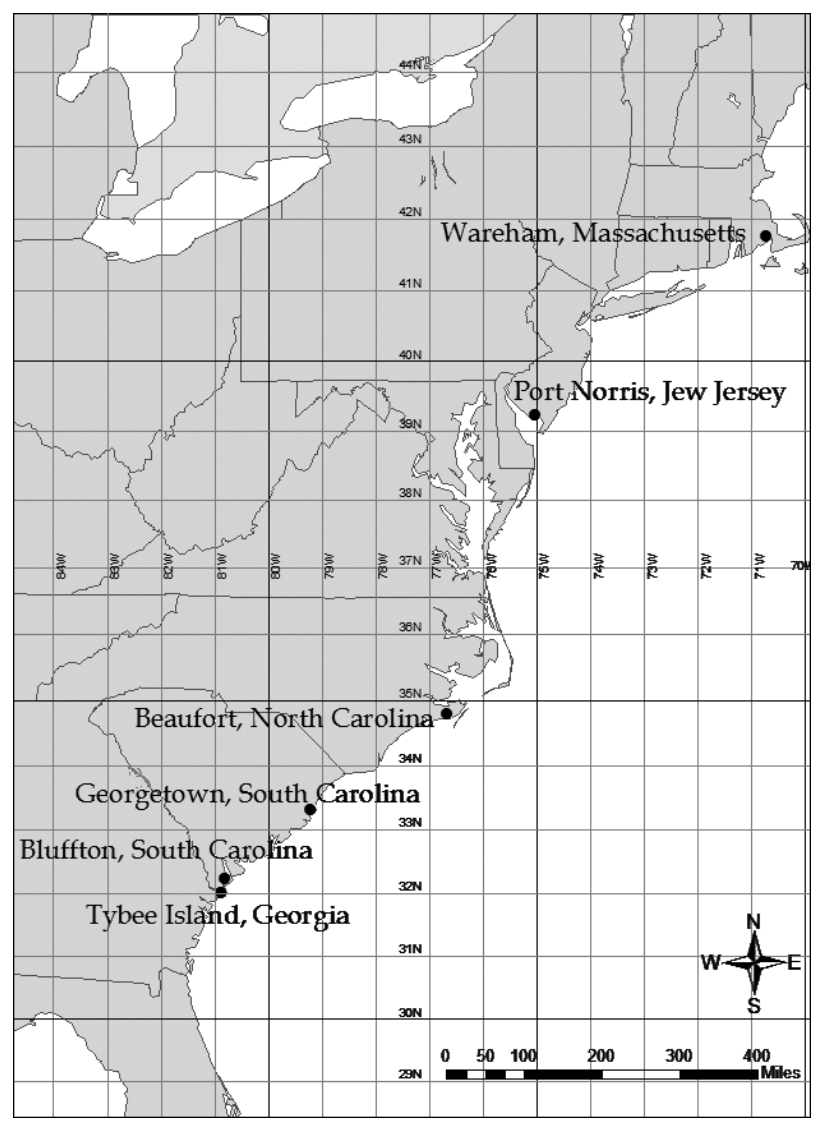

Fig. 1. Location of collection sites along the east coast of the USA with an analytical balance $(0.0001 \mathrm{~g})$. The HSI was defined as the percentage by mass of the hepatopancreas compared to the whole body: (dry mass of the hepatopancreas / dry mass of the crab including the hepatopancreas) $\times 100$. For males, we excluded the large claw mass from the dry weight measurement because bigger males have disproportionately larger claws than smaller males, which could potentially bias the HSI results (cf. Yamaguchi 2001). Furthermore, males often lose their claws in combat and subsequently molt back similarly-sized lighter claws (Backwell et al. 2000).

Female crabs were inspected for their reproductive status at all sites throughout the study period, except for Bell Creek, NC, on 12 July 2012 (reproductive status was added as a variable after the processing of this batch of crabs, which was the first to be dissected). Ovarian development was assessed macroscopically (cf. Castiglioni et al. 2007); ovaries that were swollen and a light pink to a dark burgundy in color or filled with visible oocytes were scored as 'developed,' while ovaries that were transparent and thin were scored as 'undeveloped.' For ovaries scored as 'undeveloped,' we did not differentiate ovaries that were spent from a recent spawning from those in a resting state. Ovigerous females with extruded, externally attached embryos were dissected, dried and weighed after the embryos were removed.

To record burrow water temperature during the study, Tidbit temperature loggers (Onset model UTBI-001) were placed within crab habitats in simulated burrows, made of $0.7 \mathrm{~m}$ long slotted PVC tubes hammered into the substratum, extending below the water table. At each location, 3 loggers were placed within 2 to $3 \mathrm{~m}$ of each other and their data were averaged for hourly data points $\left({ }^{\circ} \mathrm{C}\right)$. Only data from loggers from MA and NC were used because they were in place the longest and recorded temperatures during important seasonal transitions. Loggers placed in habitats in SC and GA were installed for shorter periods and did not yield useful data; also, several were lost or stolen.

\section{Statistical analysis}

General linear models (GLMs) were used to examine the effects of latitude (categorical) and season (categorical) on HSI (continuous) in males and females. Size (carapace width) was not included as a covariate since exploratory analyses indicated that crab size differences between sites did not contribute to variation in HSI. We examined how female crab HSI 
Table 1. Locations and collection dates (given as day-month-year) for all specimens used in this study. Carapace width is mean \pm SE $(\mathrm{mm})$

\begin{tabular}{|c|c|c|c|c|c|}
\hline Location & $\begin{array}{l}\text { Collection } \\
\text { dates }\end{array}$ & Season & $\begin{array}{l}\text { Males } \\
\text { (n) }\end{array}$ & $\begin{array}{c}\text { Females } \\
\text { (n) }\end{array}$ & $\begin{array}{l}\text { Ovigerous } \\
\text { females? }\end{array}$ \\
\hline \multicolumn{6}{|l|}{ Massachusetts (MA) } \\
\hline Buzzards Bay & 24-Jun-12 & Summer & 13 & 3 & Yes \\
\hline Buzzards Bay & 2-Jul-12 & Summer & 19 & 3 & Yes \\
\hline Buzzards Bay & 8-Jul-12 & Summer & 11 & 19 & Yes \\
\hline Buzzards Bay & 11-Sep-12 & Fall & 19 & 17 & No \\
\hline Buzzards Bay & 13-May-13 & Spring & 20 & 21 & Yes \\
\hline Buzzards Bay & 12-Jul-13 & Summer & 32 & 24 & Yes \\
\hline Carapace width & & & $14.3 \pm 0.3$ & $12.5 \pm 0.2$ & \\
\hline \multicolumn{6}{|l|}{ New Jersey (NJ) } \\
\hline Maurice River Marsh & 29-Sep-12 & Fall & 22 & 21 & Yes \\
\hline Maurice River Marsh & $24-A p r-13$ & Spring & 18 & 11 & No \\
\hline Maurice River Marsh & 1-Jul-13 & Summer & 18 & 20 & Yes \\
\hline Carapace width & & & $11.6 \pm 0.4$ & $10.7 \pm 0.3$ & \\
\hline \multicolumn{6}{|l|}{ North Carolina (NC) } \\
\hline Bell Creek & 13-Jul-12 & Summer & 19 & 20 & - \\
\hline Bell Creek & 15-Sep-12 & Fall & 20 & 23 & Yes \\
\hline Bell Creek & 22-Apr-13 & Spring & 16 & 14 & No \\
\hline Bell Creek & 18-Jul-13 & Summer & 22 & 22 & Yes \\
\hline Carapace width & & & $16.6 \pm 0.3$ & $15.0 \pm 0.2$ & \\
\hline \multicolumn{6}{|l|}{ South Carolina (SC1, SC2) } \\
\hline Marsh Road, Belle Baruch Field Laboratory (SC1) & 18-Jul-12 & Summer & 20 & 19 & Yes \\
\hline Carapace width & & & $17.2 \pm 0.4$ & $15.1 \pm 0.4$ & \\
\hline Buckingham landing, Bluffton (SC2) & 8-Oct-12 & Fall & 20 & 19 & No \\
\hline Buckingham landing, Bluffton (SC2) & 27-Apr-13 & Spring & 19 & 20 & No \\
\hline Buckingham landing, Bluffton (SC2) & 28-Jul-13 & Summer & - & 12 & Yes \\
\hline Buckingham landing, Bluffton (SC2) & 20-Aug-13 & Summer & 19 & - & - \\
\hline Carapace width & & & $17.0 \pm 0.3$ & $12.2 \pm 0.3$ & \\
\hline \multicolumn{6}{|l|}{ Georgia (GA) } \\
\hline Tybee Island & 17-Jul-12 & Summer & 17 & 20 & Yes \\
\hline Tybee Island & 2-Nov-12 & Fall & 16 & 17 & No \\
\hline Tybee Island & $26-A p r-13$ & Spring & 22 & 10 & Yes \\
\hline Tybee Island & 1-May-13 & Spring & - & 18 & Yes \\
\hline Tybee Island & 13-July-13 & Summer & 16 & 19 & Yes \\
\hline Tybee Island & 19-July-13 & Summer & - & 11 & Yes \\
\hline \multirow[t]{2}{*}{ Carapace width } & & & $17.3 \pm 0.3$ & $13.9 \pm 0.2$ & \\
\hline & Total & & 398 & 383 & \\
\hline
\end{tabular}

varied with an investment in reproduction, using a 1way ANOVA to compare HSI in females collected during the summer months (late June through July) with undeveloped ovaries, developed ovaries, and extruded embryos. For both sexes, we used ANCOVAs to examine seasonal and latitudinal changes in body mass (dry weight; g), and included carapace width $(\mathrm{mm})$ as a covariate. The sexes were examined separately because removing the large claw from the male analyses made the HSI and body mass measures qualitatively different for males compared to females. Square root transformed values of HSI and body mass were used to correct their non-normal distributions.
Sites in GA, NC, and MA were sampled at every season during the study period. However, the Georgetown, SC, site (SC1) was sampled only in summer 2012, while the Bluffton, SC (SC2) and NJ sites were added after the summer of 2012 and sampled in fall 2012, spring 2013, and summer 2013. For this reason, 2 GLMs were done for each sex-one using all of the data from all 6 sites, and another using only data from the 3 sites for which there was a complete set of samples. Because the HSI analyses using 3 versus 6 sites did not yield qualitatively different results, the larger analyses are presented below. Only the GA, NC, and MA sites were used to 
assess changes in body mass, as this investigation specifically looked at the seasonal changes in overall body condition to inform our understanding of HSI patterns. IBM SPSS Statistics 22.0 was used for all statistical analyses.

\section{RESULTS}

\section{Geographic and seasonal patterns in HSI}

Between 24 June 2012 and 28 July 2013, a total of 383 female and 398 male crabs were collected from 6 sites between the latitudes of $41.7615^{\circ} \mathrm{N}$ and $32.0139^{\circ} \mathrm{N}$ along the Uca pugnax range (Table 1) and assessed for hepatosomatic index (HSI), body mass, and reproductive variables.

\section{Females}

We found a highly significant interaction between season and latitude for HSI in females $(p<0.001$; Table 2, Fig. 2). At the more southerly sites, seasonal variation in HSI was greater than it was at the more northerly sites. In GA, for example, HSI decreased from $4.44 \pm$ 0.35 (mean \pm SE) in summer 2012 to $1.66 \pm 0.14$ in the fall of that year, whereas in MA, HSI decreased from $3.54 \pm 0.35$ to $3.45 \pm 0.24$ over that same period. HSI for females ranged from $1.66 \pm 0.14(\mathrm{n}=17)$ in fall 2012 in GA to $4.84 \pm 0.44(\mathrm{n}=14)$ in spring 2013 in $\mathrm{NC}$, with an average of $3.46 \pm 0.08(\mathrm{n}=383)$ for all sites over the study period.

For females at the 3 sites that were sampled on all 4 occasions (MA, NC, GA), body mass showed the same pattern as HSI. There was a significant interaction between site and season $\left(F_{6,248}=8.16, \mathrm{p}<0.001\right)$, and females at the southern sites, GA and $\mathrm{NC}$, showed larger fluctuations in body mass compared to conspecifics in MA. The lowest body masses were found in fall 2012 at the 2 southern sites.

Table 2. General linear model analysis of square root transformed values of the hepatosomatic index (HSI) of female Uca pugnax as a function of season (summer, fall, and spring) and location (latitude). $\mathrm{R}^{2}=0.228$ (adjusted $\mathrm{R}^{2}=$ 0.190)

\begin{tabular}{|lccccc|}
\hline Source & Type III SS & df & MS & $F$ & $p$ \\
\hline Corrected model & 18.203 & 18 & 1.011 & 5.973 & 0.000 \\
Intercept & 1070.230 & 1 & 1070.230 & 6321.676 & 0.000 \\
Season & 4.521 & 3 & 1.507 & 8.902 & 0.000 \\
Latitude & 1.743 & 5 & 0.349 & 2.059 & 0.070 \\
Season $\times$ Latitude & 10.147 & 10 & 1.015 & 5.994 & 0.000 \\
Error & 61.623 & 364 & 0.169 & & \\
Total & 1327.797 & 383 & & & \\
Corrected total & 79.826 & 382 & & & \\
\hline
\end{tabular}

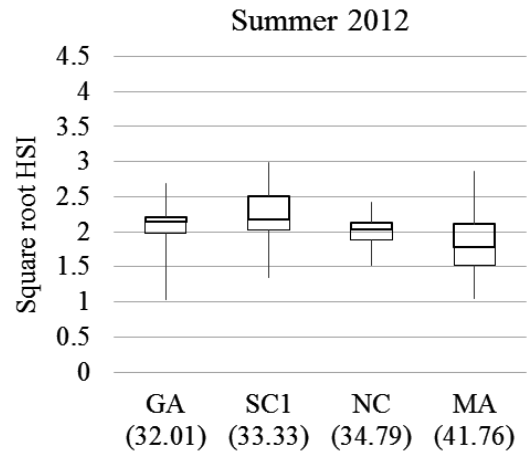

Fall 2012
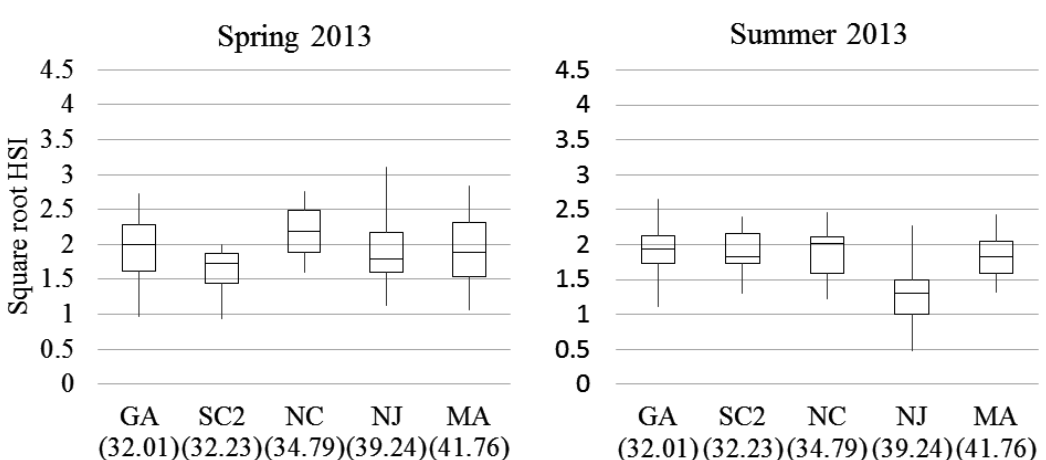

Fig. 2. Square root transformed values of female UCa pugnax hepatosomatic index (HSI) along the species' range from summer 2012 to summer 2013. Location labels correspond to collection sites in Table 1. Boxes show interquartile ranges and the horizontal lines within boxes show the medians; whiskers extend to highest and lowest values. Numbers in parentheses on the $x$-axis are degrees latitude north

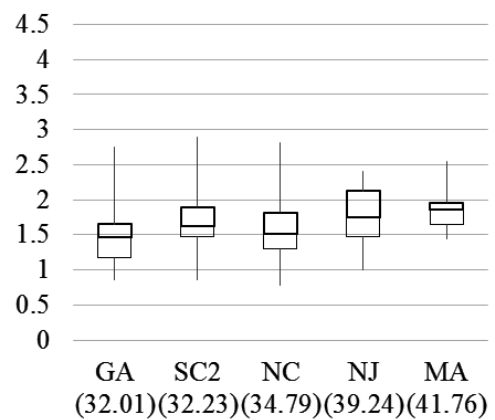

\section{.}

(1)

(1)

(1) 
Table 3. General linear model analysis of square root transformed values of the hepatosomatic index (HSI) of male Uca pugnax as a function of season (summer, fall, and spring) and location (latitude). $\mathrm{R}^{2}=0.189$ (adjusted $\mathrm{R}^{2}=0.151$ )

\begin{tabular}{|lccccc|}
\hline Source & Type III SS & df & MS & $F$ & $p$ \\
\hline Corrected model & 21.847 & 18 & 1.214 & 4.915 & 0.000 \\
Intercept & 1461.212 & 1 & 1461.212 & 5917.457 & 0.000 \\
Season & 7.715 & 3 & 2.572 & 1.837 & 0.000 \\
Latitude & 2.268 & 5 & 0.454 & 10.414 & 0.105 \\
Season $\times$ Latitude & 10.499 & 10 & 1.050 & 4.252 & 0.001 \\
Error & 93.587 & 379 & 0.247 & & \\
Total & 1790.653 & 398 & & & \\
Corrected total & 115.434 & 397 & & & \\
\hline
\end{tabular}
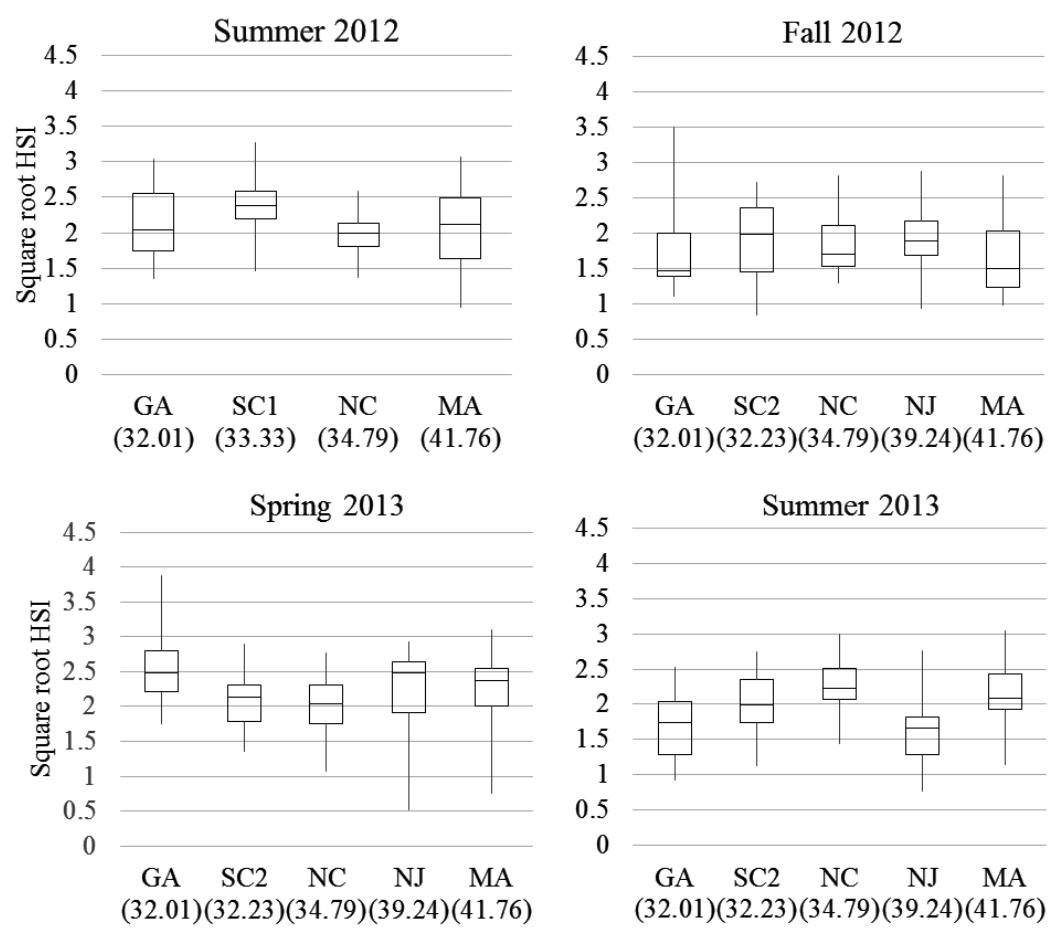

Fig. 3. Square root transformed values of male Uca pugnax hepatosomatic index (HSI) along the species' range from summer 2012 to summer 2013. Location labels correspond to collection sites in Table 1. See legend to Fig. 2 for explanation of boxplots

the seasons compared to northerly conspecifics, although the summer to fall pattern was not as clear for males as it was for females. In males, HSI ranged from $2.99 \pm 0.46(n=18)$ in summer 2013 in NJ to 6.81 $\pm 0.57(\mathrm{n}=22)$ in spring 2013 in GA, with an average of $4.50 \pm 0.11(\mathrm{n}=398)$ for the study period.

There was a significant interaction between site and season for male body mass (whole body dry mass with large claw excluded) at the 3 sites that were sampled on all 4 occasions (MA, NC, GA; $F_{6,249}=$ 4.04, $\mathrm{p}=0.001$ ). Males in GA and NC experienced much greater seasonal fluctuations in body mass compared to males in MA. For all sites, fall body masses were lowest compared to the other seasons.

\section{HSI and female reproductive status}

In specimens collected along the range during the 2012 and 2013 reproductive seasons (late June through July), average HSI varied significantly with female reproductive status $\left(F_{2,169}=15.449, \mathrm{p}<0.001\right.$; Tukey's HSD; Fig. 4). Average HSI was highest at $4.28 \pm 0.18(\mathrm{n}=54)$ in females with developed ovaries, but without extruded embryos (Fig. 4). Females that were ovigerous and those with undeveloped ovaries (either spent from a recent spawning or in a resting state) had average HSIs of $2.49 \pm 0.30(\mathrm{n}=27)$ and $3.47 \pm$ $0.16(\mathrm{n}=91)$, respectively. Females collected from Bell Creek, NC, on 12 July 2012 were not included in this analysis because their reproductive status was not recorded.

\section{Reproductive condition and water temperature}

The pattern of occurrence of ovigerous females in our collections suggested that the reproductive season was shorter in the northern compared to the southern part of the range. Ovigerous females were found in GA on 26 April, but no ovigerous females were found in the spring collections in $\mathrm{SC} 2, \mathrm{NC}$, and $\mathrm{NJ}$ on 27,22 , and 24 April, respectively, in 2013. In NC that same year, females had developed ovaries on 22 April and burrow water reached $18 \mathrm{C}$, the temperature permissible for larval development in coastal waters, on 10 May (Fig. 5). The spring collection in MA took place on 13 May 2013, and ovigerous females were found in this collection although burrow water temperature did not reach $18^{\circ} \mathrm{C}$ until 23 d later, on 3 June (Fig. 5). Ovigerous females were found at all sites in the summer collections during the month of July in 2012 and 2013. In the fall, ovigerous females were not found on 11 September 2013 in MA, but they were present in 


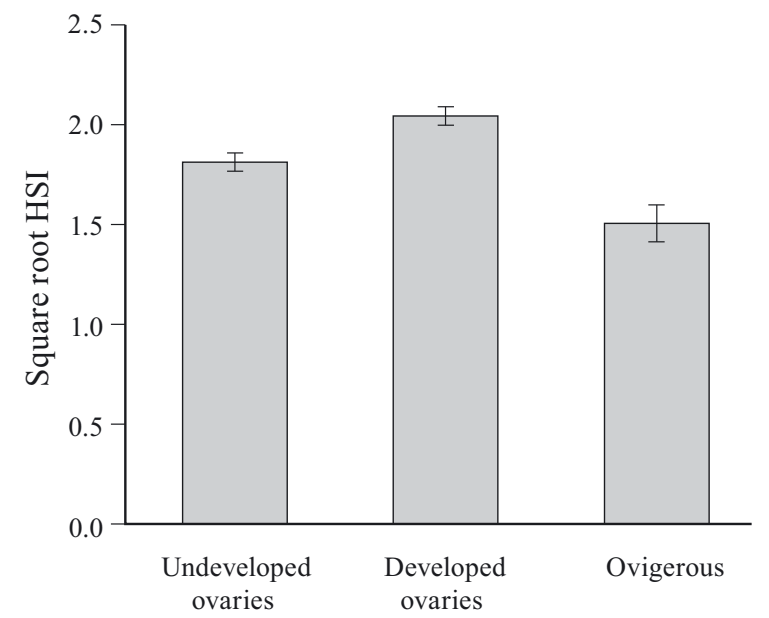

Fig. 4. Reproductive status and hepatosomatic index (HSI; mean $\pm \mathrm{SE}$ ) for female crabs Uca pugnax collected in summers 2013 and 2014 at all sites sampled along its range (see Table 1). Tukey pairwise comparisons of mean square root HSI were all significant: Undeveloped ovaries/Developed ovaries $(\mathrm{p}=0.004)$; Undeveloped ovaries/Ovigerous $(\mathrm{p}=$ 0.003); Developed ovaries/Ovigerous $(p<0.001)$

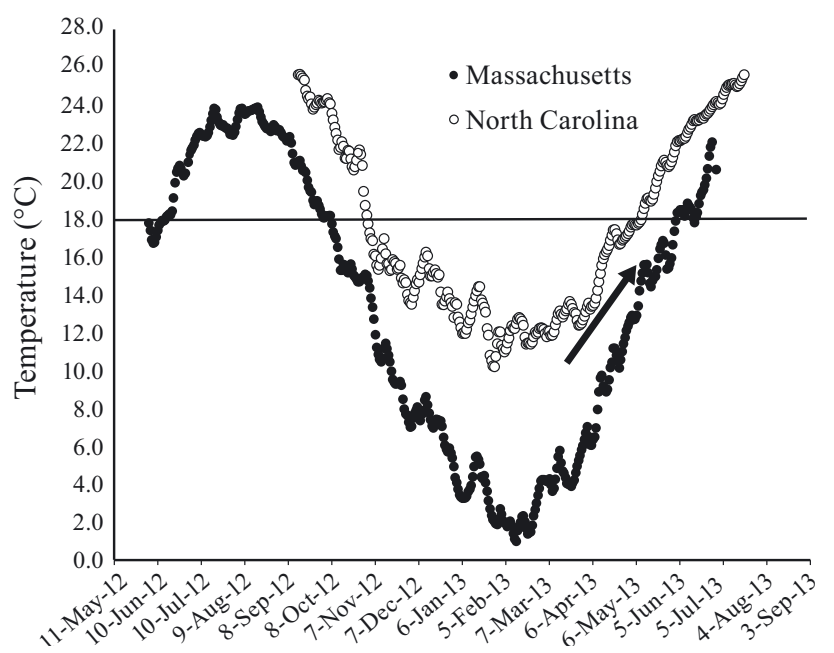

Fig. 5. Temperature measurements from PVC pipe burrows placed in Uca pugnax habitats in Massachusetts and North Carolina. The temperature record does not span the entire period over which specimens were collected for this study. The horizontal line indicates $18^{\circ} \mathrm{C}$, the minimal temperature at which larval development can be completed for this species. In Massachusetts, ovigerous females were found during a collection that was made when sea surface temperature was too cold for larval development (arrow). The $x$-axis shows $30 \mathrm{~d}$ increments

the collections from NJ on 29 September and in NC on 15 September of that same year. The fall collections that year in SC2 and GA were later, on 8 October and 2 November, respectively, and no ovigerous females were found.

\section{DISCUSSION}

Uca pugnax is currently extending its range northward in response to warming conditions in the Northeast Atlantic. The close tracking of ocean temperatures is likely facilitated by the unimpeded colonization of more northern habitats by the planktonic larval stage, a scenario that was predicted by Sanford et al. (2006) and then documented by Johnson (2014). Two years before the range shift was documented, we collected hundreds of male and female adult crabs from habitats along a latitudinal transect from Wareham, MA, to Tybee Island, GA, to determine if there was a latitudinal cline in energy stores, as assessed by the HSI. Because northern winters shorten the duration of time that crabs are able to feed, we expected to find that northern crabs would have lower energy stores, overall, and would be more challenged with maintaining those stores over the course of the year compared to their southern conspecifics.

We did not find a simple latitudinal cline in HSI for male and female $U$. pugnax; instead, we found a more complex and highly significant latitude $\times$ season interaction that differed for the 2 sexes. Compared to northern conspecifics, southern females and males experienced greater changes in energy stores and body mass throughout the year. For southern females, HSI and body mass dropped from summer to fall in 2012 and then increased again in spring and summer 2013. For females at the northernmost site (MA), both HSI and body mass remained fairly constant over the course of the study. The fact that we were able to detect fluctuations in HSI at the southern sites suggests that seasonal changes in body fat were more pronounced than seasonal body mass changes because if hepatopancreas and body masses had changed proportionately, HSI (a ratio) would have remained unchanged.

Across the range, HSI values dropped for males between summer and fall 2012, rose again in spring 2013, and were declining again during summer 2013, and those changes were larger in the southern populations compared to the northernmost population. For males, body mass remained relatively stable at the northernmost site throughout the study, while there were larger fluctuations in body mass throughout the year in the southern populations.

In general, our sampling regime did not allow us to collect from populations at comparable points in their reproductive seasons. While this would have been difficult to predict in advance, the repercussions of our approach must still be considered. For example, 
females in GA would have been reproducing for longer than females in populations to the north of them when the summer collections were made. We found that the reproductive season for populations in the north began later and ended earlier compared to the southern populations, corroborating what others have found (e.g. Williams 1984, Sanford et al. 2006). Consequently, in our summer sample, it is quite possible that the southern females would have released more broods. In several other Uca species, it has been found that females release consecutive broods when they are able to surface feed while incubating embryos - a feat that is achievable for species with small, well-protected broods occupying lower, wetter habitats (Koga et al. 2000, Henmi 2003). In contrast, Uca species living in higher, drier habitats fast while incubating larger broods in burrows and do not continuously reproduce because they require a recovery period after each brood. U. pugnax has relatively small broods, occupies well saturated areas, and is able to feed on the surface while ovigerous (J. Christy pers. comm., R. J. Brodie pers. obs.), and some females at the SC1 site were found to breed repeatedly within a season, where the shortest interval between broods was around 1 mo (B. Greenspan unpubl. data). Furthermore, we found that HSI was significantly reduced in females that had extruded embryos, a pattern that has been found for other crab species (e.g. Alava et al. 2007, Zeng et al. 2014). Southern females could potentially produce more annual broods than northern females, and by summer, might experience more depleted fat stores if they are not able to restore those stores through feeding. It is worth noting that southern females stop producing broods in late September (Christy 1982) before water temperatures are too cold for larval development, indicating that female fat depletion rather than cold temperatures may bring the reproductive season to a close in the south. HSI is also impacted by the molt cycle (Chang 1995), although how frequently molting occurs and whether there are differences in the timing of molt cycles between populations in the wild is not known for $U$. pugnax (L. Bergey pers. comm.). We acknowledge that reproductive seasonality and molt cycle differences between populations could have created some noise in our data. However, because samples were collected throughout the year along the range, a perfect match of reproductive season was not required to detect the larger fluctuations that we found in HSI for the southern compared to northern populations.

A drop in HSI following the reproductive season has also been found for subtropical populations of
U. lactea (Yamaguchi 2001, 2003 for a population at $32.54^{\circ} \mathrm{N}$ ), and $U$. arcuata (Shih 1992 for females at $25.18^{\circ} \mathrm{N}$ ), the only other fiddler crab species for which we were able to find seasonal HSI data. The HSI range reported for female $U$. arcuata of around 2-5 (Shih 1992) was nearly identical to what we found for female $U$. pugnax (2-5), although the HSI for female $U$. lactea was larger at around 3-12 and showed a greater seasonal variation (Yamaguchi 2003). U. lactea males also showed a larger HSI of around 8-13 (Yamaguchi 2001) compared to 3-7 for $U$. pugnax males. More macrophysiological data across fiddler crab species would allow us to determine whether it is generally true that seasonal fluctuations in energy stores tend to be greater for lower compared to higher latitude populations.

Counter to our prediction, there was no evidence to suggest that the northern $U$. pugnax were challenged in their abilities to acquire and maintain energy stores even though they spend several months underground without feeding. Although we found a latitudinal pattern in the degree of seasonal fluctuation, latitude by itself did not explain variation in HSI. In this respect, $U$. pugnax resembles its East African congener, U. urvillei, another generalist species that was found to have an efficient and consistent metabolic performance across $27^{\circ}$ of latitude (Fusi et al. 2015). For both $U$. pugnax and $U$. urvillei, physiological and life history traits may explain their high performance across a broad latitudinal range. Like most Uca species, they are bimodal breathers that perform nearly all of their activities, including courtship, mating, feeding, and burrow construction while exposed at low tide (Crane 1975). As the tide rises, many Uca species retreat into their burrows which they plug with sand or mud, trapping themselves in a pocket of air for the duration of the tidal inundation (Crane 1975). While $U$. urvillei maintains an air-filled burrow (Fusi et al. 2015), U. pugnax does not always plug its burrow and sometimes feeds while submerged (Teal 1959, R. J. Brodie pers. obs.); however, both species are far more active in air compared to water. Bimodal respiration dominated by air breathing potentially broadens the window of thermal tolerance (Pörtner 2010, Fusi et al. 2016, Verberk et al. 2016), explaining, at least in part, how these species are able to populate habitats across climate zones. Finally, Uca species which spawn into coastal waters often show little genetic structure along expanses of coastline, presumably because dispersing planktonic larvae facilitate gene flow between populations (e.g. Sanford et al. 2006, Silva et al. 2010, 
Wieman et al. 2014) and reduce the potential for local adaptation, including thermal specialization.

In Massachusetts, ovigerous females were found in our early May collection, 23 d before the ocean surface was warm enough for this species to complete larval development and much earlier than has been reported for $U$. pugnax in the past. Given that the length of brood incubation for $U$. pugnax is $12-15 \mathrm{~d}$, depending on temperature (Christy 1982), this indicates that there were larvae in the water column ready to complete development as soon as conditions were permissible. Larvae released very early in the season in the north may experience increased mortality due to the adverse effects of delayed development and prolonged exposure to predators (Pechenik 2006, Vaughn \& Allen 2010); however, those which are able to develop successfully in the colder conditions will form the leading edge of the range expansion (Sanford et al. 2006).

There is evidence that the length of the reproductive season for $U$. pugnax has changed over the last half century. Crane (1975) reported that $U$. pugnax in NJ released larvae from late June to early September, but in the early 2000s, Bergey \& Weis (2008) suggested a reproductive season that extended from late April to October for a NJ population based on larval settlement patterns from 2002-2004. Our data showing earlier than expected reproduction in Massachusetts in 2013 is consistent with Bergey \& Weis (2008). However, while we found females with developed ovaries in our late April collections in $\mathrm{NJ}, \mathrm{NC}$, and $\mathrm{SC}$, none of them were ovigerous. Only females in GA were ovigerous in late April 2013, and because we did not make earlier collections, we do not know when that population actually started to produce larvae. Our data do not support the hypothesis that the reproductive season is ending later, as we found no ovigerous females in our early October collection from SC. However, the fact that we did not find ovigerous females does not mean that they were not present in the populations. Discrepancies might also be due to the qualitatively different data used to estimate reproductive season length-namely, larval settlement patterns vs. the presence of ovigerous females. Finally, if ocean conditions are affecting the length of the reproductive season for this species, then year to year variation would be expected. A more frequent sampling of several sites along the range for ovigerous females, larvae in the plankton, or recently settled juveniles over the course of several years would show the impact of changing ocean temperatures on the phenology of the reproductive season.

\section{CONCLUSION}

Uca pugnax is a potential climate change 'winner.' While wide-ranging planktonic larval dispersal via coastal currents limits its potential for local adaptation (Sanford et al. 2006), larvae that are released into northern waters in early spring as surface temperatures are becoming permissible for development can rapidly colonize new habitats. We found that adults of this species maintain similar fat stores in habitats separated by nearly $10^{\circ}$ in latitude, suggesting that they are not energetically stressed near the expanding northern range edge and have sufficient resources to invest in growth, body maintenance, and reproduction. However, while energy stores did not vary along the range during our investigation (excepting seasonal fluctuations), we know that reproductive and feeding season length does vary with latitude for this species, and metabolic rates and reproductive investment might vary as well. How $U$. pugnax is able to maintain stable energy stores over such a broad range of environmental conditions is the next question that should be addressed in this system.

Acknowledgements. We thank the many crab collectors involved in this study, including Terry Lester from the University of Georgia and students from the Duke Marine Lab in Beaufort, NC, and University of South Carolina Beaufort, Bluffton, SC. We also thank John Christy and Lauren Bergey for sharing their insights on fiddler crab reproduction and molt cycles. Bev Greenspan generously shared unpublished data on Uca pugnax brood intervals, which shed light on the potential consequences of reproductive season length differences along the range of this species, and Janice Gifford provided assistance with our statistical analysis. Finally, we are grateful for feedback on drafts of the manuscript from the Pioneer Valley Animal Behavior writing group (especially Ethan Clotfelter, Beth Jakob, and Sarah Partan) and 3 anonymous reviewers. Funding for this work was provided by faculty grants from Mount Holyoke College.

\section{LITERATURE CITED}

Alava VR, Quinitio ET, de Pedro JB, Priolo FMP, Orozco ZGA, Wille M (2007) Lipids and fatty acids in wild and pond-reared mud crab Scylla serrata (Forsskål) during ovarian maturation and spawning. Aquacult Res 38: 1468-1477

Backwell PR, Christy JH, Telford SR, Jennions MD, Passmore NI (2000) Dishonest signaling in a fiddler crab. Proc Biol Sci 267:719-724

Barnwell F, Thurman C (1984) Taxonomy and biogeography of the fiddler crabs (Ocypodidae, Genus Uca) of the Atlantic and Gulf coasts of Eastern North America. Zool J Linn Soc 81:23-87

*Bell G, Gonzalez A (2009) Evolutionary rescue can prevent extinction following environmental change. Ecol Lett 12: 942-948 
Bergey LL, Weis JS (2008) Aspects of population ecology in two populations of fiddler crabs, Uca pugnax. Mar Biol 154:435-442

Bertness M (1985) Fiddler crab regulation of Spartina alterniflora production on a New England salt marsh. Ecology 66:1042-1055

Bradshaw A, McNeilly T (1991) Evolutionary response to global climatic change. Ann Bot 67:5-14

* Buckley LB, Nufio CR, Kingsolver JG (2014) Phenotypic clines, energy balances and ecological responses to climate change. J Anim Ecol 83:41-50

Bui TH, Lee SY (2014) Does 'you are what you eat' apply to mangrove grapsid crabs? PLOS ONE 9:e89074

Castiglioni DS, Negreiros-Fransozo ML, Lopez Greco LS, Silveira AF, Silveira SO (2007) Gonad development in females of fiddler crab Uca rapax (Crustacea, Brachyura, Ocypodidae) using macro and microscopic techniques. Iheringia Ser Zool 97:505-510

* Chang ES (1995) Physiological and biochemical changes during the molt cycle in decapod crustaceans: an overview. J Exp Mar Biol Ecol 193:1-14

* Christy J (1982) Adaptive significance of semilunar cycles of larval release in fiddler crabs (Genus $U_{C a}$ ) - test of an hypothesis. Biol Bull 163:251-263

Crane J (1975) Fiddler crabs of the world: Ocypodidae: Genus Uca. Princeton University Press, Princeton, NJ

* Elumalai M, Antunes C, Guilhermino L (2005) Alterations of reproductive parameters in the crab Carcinus maenas after exposure to metals. Water Air Soil Pollut 160: 245-258

Fusi M, Giomi F, Babbini S, Daffonchio D, McQuaid CD, Porri F, Cannicci S (2015) Thermal specialization across large geographical scales predicts the resilience of mangrove crab populations to global warming. Oikos 124:784-795

Fusi M, Cannicci S, Daffonchio D, Mostert B, Pörtner HO, Giomi F (2016) The trade-off between heat tolerance and metabolic cost drives the bimodal life strategy at the airwater interface. Sci Rep 6:19158

Gittman RK, Keller DA (2013) Fiddler crabs facilitate Spartina alterniflora growth, mitigating periwinkle overgrazing of marsh habitat. Ecology 94:2709-2718

* Henmi Y (2003) Trade-off between brood size and brood interval and the evolution of underground incubation in three fiddler crabs (Uca perplexa, U. vocans, and U. dussumieri). J Crustac Biol 23:46-54

Hoffman J, Katz J, Bertness M (1984) Fiddler crab depositfeeding and meiofaunal abundance in salt-marsh habitats. J Exp Mar Biol Ecol 82:161-174

Hufbauer RA, Szucs M, Kasyon E, Youngberg C and others (2015) Three types of rescue can avert extinction in a changing environment. Proc Natl Acad Sci USA 112: 10557-10562

IPCC (Intergovernmental Panel on Climate Change) (2014) Climate change 2014: synthesis report. Contribution of Working Groups I, II and III to the Fifth Assessment Report of the Intergovernmental Panel on Climate Change. IPCC, Geneva

Johnson DS (2014) Fiddler on the roof: a northern range extension for the marsh fiddler crab Uca pugnax. J Crustac Biol 34:671-673

Katz L (1980) Effects of burrowing by the fiddler crab, UCa pugnax (Smith). Estuar Coast Mar Sci 11:233-237

Koga T, Murai M, Goshima S, Poovachiranon S (2000) Underground mating in the fiddler crab Uca tetragonon: the association between female life history traits and male mating tactics. J Exp Mar Biol Ecol 248:35-52

Kyomo J (1988) Analysis of the relationship between gonads and hepatopancreas in males and females of the crab Sesarma intermedia, with reference to resource use and reproduction. Mar Biol 97:87-93

Liu Z, Wu X, Wang W, Yan B, Cheng Y (2014) Size distribution and monthly variation of ovarian development for the female blue swimmer crab, Portunus pelagicus in Beibu Gulf, off South China. Sci Mar 78:257-268

* Miller CD, Vernberg FJ (1968) Some thermal requirements of fiddler crabs of temperate and tropical zones and their influence of geographic distribution. Am Zool 8:459-469

* Passano L (1960) Low temperature blockage of molting in Uca pugnax. Biol Bull 118:129-136

*Pechenik J (2006) Larval experience and latent effects Metamorphosis is not a new beginning. Integr Comp Biol 46:323-333

* Pörtner H (2010) Oxygen and capacity limitation of thermal tolerance: a matrix for integrating climate-related stressor effects in marine ecosystems. J Exp Biol 213:881-893

* Pülmanns N, Diele K, Mehlig U, Nordhaus I (2014) Burrows of the semi-terrestrial crab Ucides cordatus enhance $\mathrm{CO}_{2}$ release in a north Brazilian mangrove forest. PLOS ONE 9:e109532

* Romano N, Wu X, Zeng C, Genodepa J, Elliman J (2014) Growth, osmoregulatory responses and changes to the lipid and fatty acid composition of organs from the mud crab, Scylla serrata, over a broad salinity range. Mar Biol Res 10:460-471

* Sabatini SE, Chaufan G, Juarez AB, Coalova I, Bianchi L, Eppis MR, del Carmen Rios de Molina M (2009) Dietary copper effects in the estuarine crab, Neohelice (Chasmagnathus) granulata, maintained at two different salinities. Comp Biochem Physiol C Toxicol Pharmacol 150: 521-527

* Sanford E, Holzman SB, Haney RA, Rand DM, Bertness MD (2006) Larval tolerance, gene flow, and the northern geographic range limit of fiddler crabs. Ecology 87:2882-2894

Seebacher F, White CR, Franklin CE (2015) Physiological plasticity increases resilience of ectothermic animals to climate change. Nat Clim Chang 5:61-66

Shih J (1992) Annual pattern of sex steroid-like substance levels in the hemolymph of female $U_{c a}$ arcata. Bull Inst Zool Acad Sinica 31:47-56

* Silva IC, Mesquita N, Paula J (2010) Lack of population structure in the fiddler crab Uca annulipes along an East African latitudinal gradient: genetic and morphometric evidence. Mar Biol 157:1113-1126

* Silva-Castiglioni D, Valgas AAN, Machado ID, Freitas BS, Oliveira GT (2016) Effect of different starvation and refeeding periods on macromolecules in the haemolymph, digestive parameters, and reproductive state in Aegla platensis (Crustacea, Decapoda, Aeglidae). Mar Freshw Behav Physiol 49:27-45

* Smith SM, Green CW (2015) Sediment suspension and elevation loss triggered by Atlantic mud fiddler crab (UCa pugnax) bioturbation in salt marsh dieback areas of southern New England. J Coast Res 31:88-94

* Smith SM, Tyrrell MC (2012) Effects of mud fiddler crabs (Uca pugnax) on the recruitment of halophyte seedlings in salt marsh dieback areas of Cape Cod (Massachusetts, USA). Ecol Res 27:233-237

Somero GN (2010) The physiology of climate change: how potentials for acclimatization and genetic adaptation will determine 'winners' and 'losers'. J Exp Biol 213:912-920 
Stillman J (2002) Causes and consequences of thermal tolerance limits in rocky intertidal porcelain crabs, Genus Petrolisthes. Integr Comp Biol 42:790-796

Sunday JM, Bates AE, Dulvy NK (2012) Thermal tolerance and the global redistribution of animals. Nat Clim Chang 2:686-690

Sunday JM, Bates AE, Kearney MR, Colwell RK, Dulvy NK, Longino JT, Huey RB (2014) Thermal-safety margins and the necessity of thermoregulatory behavior across latitude and elevation. Proc Natl Acad Sci USA 111: 5610-5615

Teal J (1958) Distribution of fiddler crabs in Georgia salt marshes. Ecology 39:185-193

Teal J (1959) Respiration of crabs in Georgia salt marshes and its relation to their ecology. Physiol Zool 32:1-14

Thomas CR, Blum LK (2010) Importance of the fiddler crab Uca pugnax to salt marsh soil organic matter accumulation. Mar Ecol Prog Ser 414:167-177

Vaughn D, Allen JD (2010) The peril of the plankton. Integr Comp Biol 50:552-570

Verberk WC, Bartolini F, Marshall DJ, Pörtner HO, Terblanche JS, White CR, Giomi F (2016) Can respiratory physiology predict thermal niches? Ann NY Acad Sci 1365:73-88

Wang X, Li E, Qin JG, Wang S and others (2014) Growth, body composition, and ammonia tolerance of juvenile white shrimp Litopenaeus vannamei fed diets containing different carbohydrate levels at low salinity. J Shellfish Res 33:511-517

Weissburg M (1993) Sex and the single forager - gender

Editorial responsibility: Bernard Sainte-Marie,

Mont-Joli, Quebec, Canada specific energy maximization strategies in fiddler crabs. Ecology 74:279-291

*Wieman AC, Berendzen PB, Hampton KR, Jang J and others (2014) A panmictic fiddler crab from the coast of Brazil? Impact of divergent ocean currents and larval dispersal potential on genetic and morphological variation in $U C a$ maracoani. Mar Biol 161:173-185

Williams AB (1984) Shrimps, lobsters, and crabs of the Atlantic coast of the Eastern United States, Maine to Florida. Smithsonian Institution Press, Washington, DC

Wolcott TG (1988) Ecology. In: Burggren WW, McMahon BR (eds) Biology of the land crabs. Cambridge University Press, New York, NY. p 55-96

Wootton JT, Pfister CA (2015) Processes affecting extinction risk in the laboratory and in nature. Proc Natl Acad Sci USA 112:E5903

* Yamaguchi T (2001) Seasonal change of the hepatopancreas index in the males of the fiddler crab, Uca lactea. Crustaceana 74:627-634

Y Yamaguchi T (2003) Seasonal changes in the energy content of females of the fiddler crab, Uca lactea, especially during the reproductive period. Crustaceana 76:1371-1397

Z Zara FJ, Gaeta HH, Costa TM, Toyama MH, Caetano FH (2013) The ovarian cycle histochemistry and its relationship with hepatopancreas weight in the blue crab Callinectes danae (Crustacea: Portunidae). Acta Zool 94: 134-146

Zeng Y, McLay C, Yeo DCJ (2014) Capital or income breeding crabs: Who are the better invaders? Crustaceana 87 : 1648-1656

Submitted: August 1, 2016; Accepted: July 11, 2017 Proofs received from author(s): August 15, 2017 